J. Perinat. Med. 4 (1976) 227

\title{
Transference of para-amino-hippurate from the mother to the amniotic fluid
}

\author{
0. Althabe, G. Sabini, A. Basso, A. Fernández, D. Torrado, R. Belitzky, R. Caldeyro- \\ Barcia
}

Latin American Center for Perinatology and Human Development (PAHO/WHO), Department of Physiopathology, Medical Faculty, Montevideo, Uruguay

To our knowledge there are few studies which analyze the time course of the concentration in amniotic fluid of alien substances administered to women during pregnancy. This is particularly true for those substances mainly cleared by the kidney into the urine.

HANON et al. [7] gave orally para-amino-hippurate (PAH) to mothers during labor and found that about two hours later, the concentration of PAH in amniotic fluid was higher than that of maternal plasma. BRANDES et al. [4] showed that inulin passed from the mother to the fetus during late pregnancy but RosA [9] administering this substance to the mother, could not find it in serial samples of amniotic fluid.

Recently BASSO et al. [2] demonstrated that mannitol administered to the mother appears in amniotic fluid at increasing concentrations reaching values higher than those found in simultaneous samples of maternal plasma.

This type of studies may contribute to the knowledge of fetal renal function and its role in the formation of amniotic fluid, as well as the transference of substances through the mother-fetusamniotic fluid complex.

\section{Material and methods}

Thirteen pregnant women were studied. In two of them fetuses had died at 36 weeks of gestation between 36 and 72 hours before the study was

\section{Curriculum vitae}

OMAR ALTHABE studied in Buenos Aires and graduated from the National University in 1955. During 1963-1965 he was a research fellow at the Servicio de Fisiología Obstétrica' in Montevideo, Uruguay. Since then his work is dedicated to clinical research in Perinatology. In 1970 he was appointed as Medical Officer, Perinatologist, of the Pan American Health Organization (PAHO/WHO) at the Latin American Center of Perinatology and Human Development, Montevideo, Uruguay where he is still working.

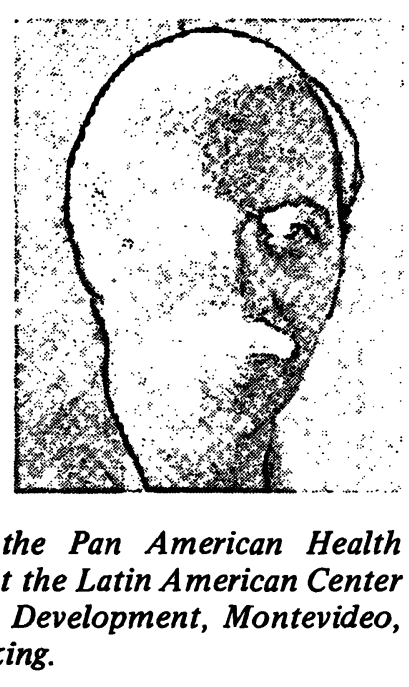

performed. In the remaining 11 subjects with live fetuses, amniotic fluid studies were performed to determine gestational age which was unknown. The results of these studies as well as the examination of the neonate indicated that the pregnancies were at term.

In all cases, transabdominal amniocentesis was performed and a catheter was placed into the amniotic cavity. Also, a maternal vein of the arm was catheterized.

The 13 pregnant women received a single $i / v$ injection of $\mathrm{PAH}$ at a rate of $8 \mathrm{mg} / \mathrm{Kg}$, followed by an intravenous infusion of the same substance. In 11 mothers the infusion rate was $380 \mathrm{mcg} / \mathrm{min} / \mathrm{Kg}$ 
for 30 minutes, in one mother $240 \mathrm{mcg} / \mathrm{min} / \mathrm{Kg}$ for 160 minutes and in the remaining subject it was $50 \mathrm{mcg} / \mathrm{min} / \mathrm{Kg}$ for 450 minutes.

Samples of maternal venous blood and amniotic fluid were simultaneously obtained, immediately before PAH administration and every 30 minutes thereafter. PAH concentration was measured in each sample using a microtechnique developed at our laboratory which is a modification of that described by HAMBURGER [6].

\section{Results}

Figure 1 show the results obtained in a mother with live fetus who received the infusion at the lowest rate $(50 \mathrm{mcg} / \mathrm{min} / \mathrm{Kg})$ during 450 minutes.

In maternal plasma, after an initial rise, PAH concentration remains almost steady, up to the end of the infusion. In amniotic fluid, there is a continuous rise of $\mathrm{PAH}$ concentration from the beginning until the end of the infusion. At 5 hours, $\mathrm{PAH}$ concentration becomes equal to that of maternal palsma and from there on the values observed in amniotic fluid were higher. At the end of infusion (07:30 hours) PAH concentration in amniotic fluid was $50 \%$ higher than in maternal plasma. After the end of the infusion the concentration in maternal plasma fell rapidly whereas in amniotic fluid it showed a very small and slow decline. Three hours after the end of the infusion, concentration in amniotic fluid was still higher than that found in blood during the infusion.

Figure 2 shows another study performed in a subject with live fetus receiving the infusion at a rate of $240 \mathrm{mcg} / \mathrm{min} / \mathrm{Kg}$ during 160 minutes. Samples of amniotic fluid were obtained more frequently than in the previous study, particularly during the first 30 minutes. Already at the second minute after the beginning of PAH administration, this substance is detected in amniotic fluid at a concentration of $0,3 \mathrm{mcg} / \mathrm{ml}$. The increment of PAH concentration in amniotic fluid continued during the infusion and even for two hours after its interruption, although concentrations in maternal plasma fell very rapidly.

In this subject, the concentration of the substance in anniotic fluid did not attain the concentration in maternal plasma probably because the duration of the infusion is not long enough. Two hours after the end of drug administration, PAH in amniotic fluid began to decrease very slowly (from 11 to $6 \mathrm{mcg} / \mathrm{ml}$ in 5 hours).

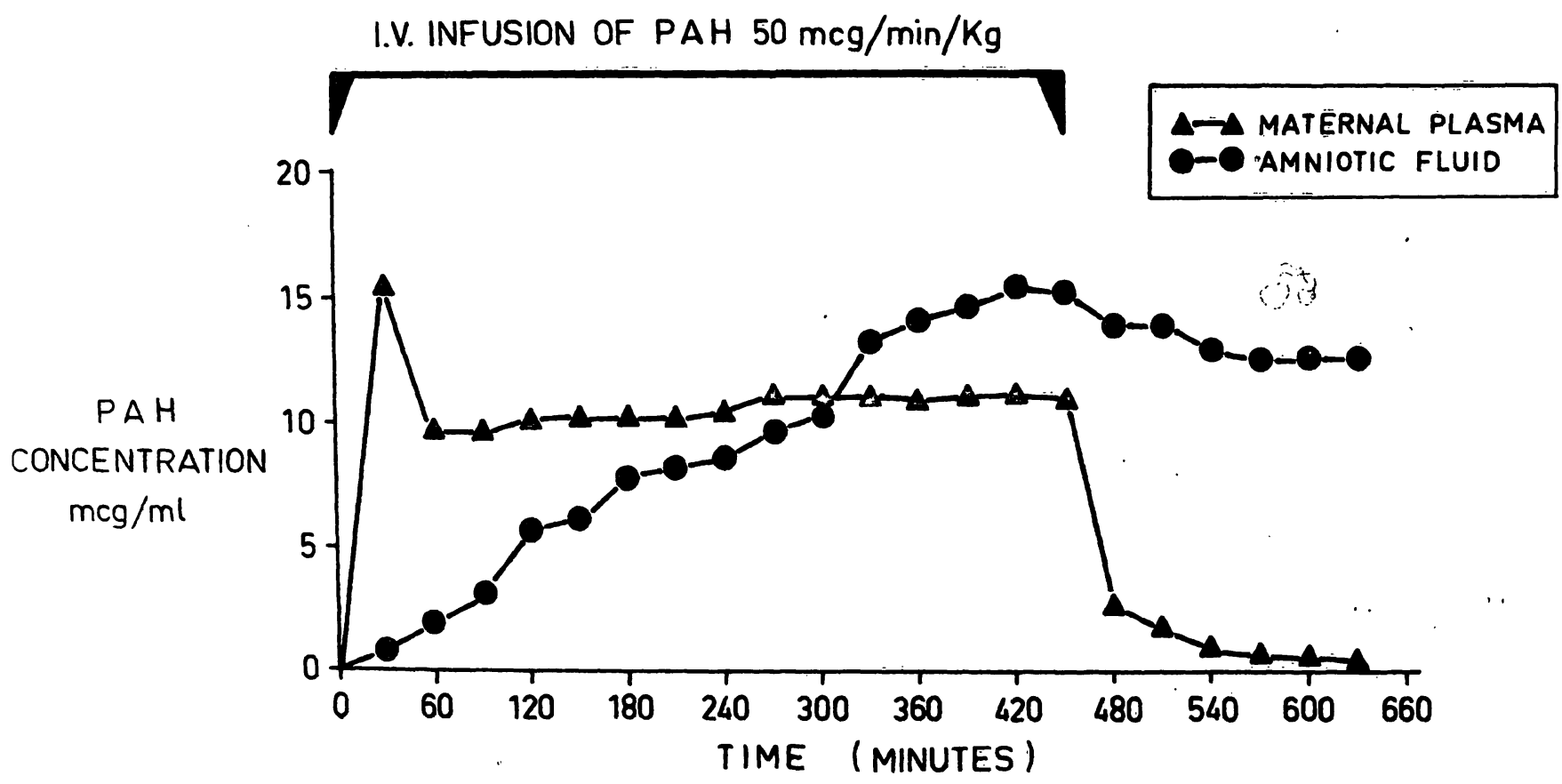

Fig. 1. See the continuous rise of PAH concentration in amniotic fluid. At 5 hours this concentration becomes equal to that of maternal plasma and at the end of the infusion, the concentration of PAH in amniotic fluid is $50 \%$ higher than maternal plasma. The study was performed during induction of labor. 


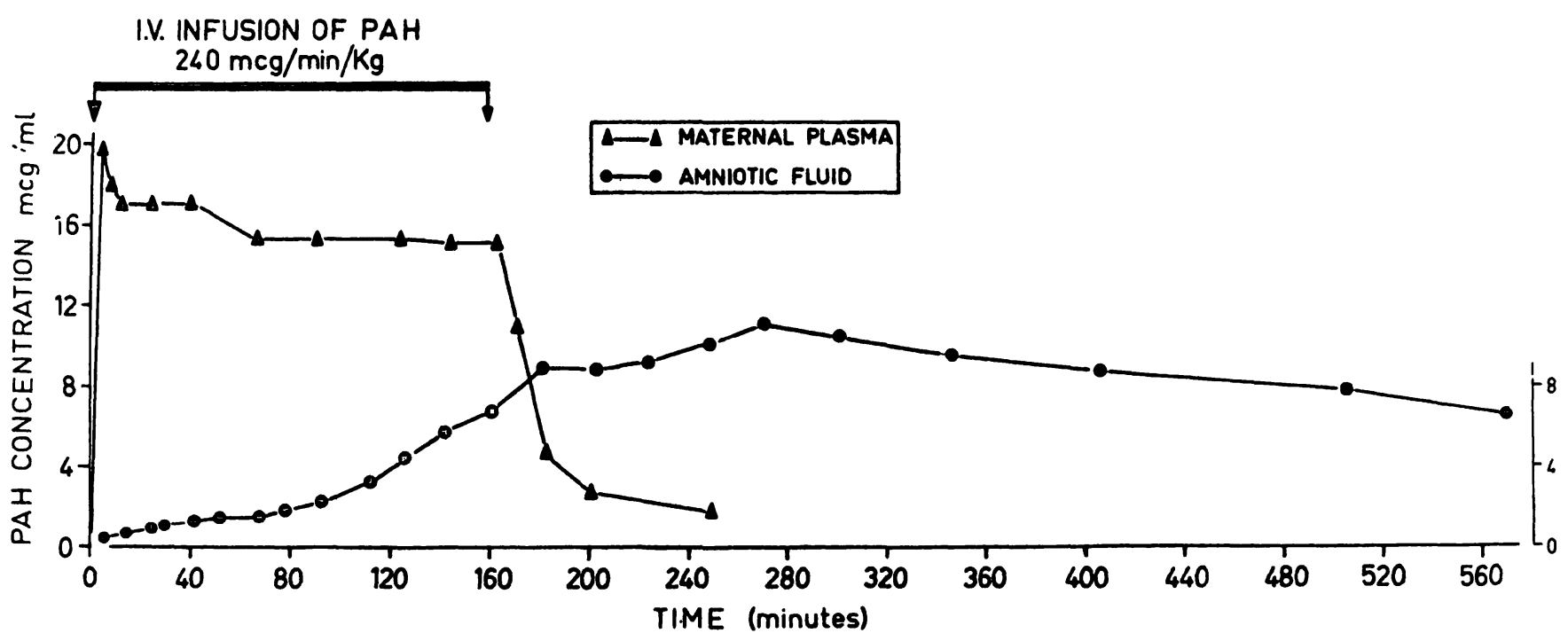

Fig. 2. Already at the second minute after PAH administration, this substance is detected in amniotic fluid. PAH concentration increases until two hours after the end of the infusion and thereafter, it begins to decrease at a slow rate (45\% in 5 hours). This study was also performed during induction of labor.

Tab. I. PAH concentrations in amniotic fluid of nine pregnant women who after the initial dose of $8 \mathrm{mg} / \mathrm{Kg} \mathrm{received} \mathrm{i} / \mathrm{v}$ infusions of $\mathrm{PAH}$ at a rate of $380 \mathrm{mcg} / \mathrm{min} / \mathrm{Kg}$ during 30 minutes.

\begin{tabular}{llccccccc}
\hline \multicolumn{7}{l}{ PAH concentration in amniotic fluid (mcg/ml) } \\
No. & Min/30 & \multicolumn{1}{c}{ 60 } & \multicolumn{1}{c}{90} & 120 & 150 & 180 & 210 & 240 \\
\hline 1 & 1.8 & 5.1 & 5.4 & 9 & 9 & 10.8 & 10.2 & 10.8 \\
2 & 0.9 & 1.5 & 3.3 & 5.1 & 7.2 & 8.1 & 7.5 & 7.2 \\
3 & 8.7 & 11.7 & 12 & 12.6 & 13.5 & 14.4 & 13.8 & 13.5 \\
4 & 1.5 & 6.3 & 9.3 & 11.4 & 11.7 & 12 & 12.3 & 10.2 \\
5 & 0.6 & 1.5 & 2.1 & 13.2 & 23.7 & 26.7 & 25.2 & 21.6 \\
6 & 4.25 & 8.25 & 16.05 & 16.35 & 16.65 & 16.35 & 16.35 & 15.65 \\
7 & 7.07 & 13.62 & 14.67 & 17.97 & 20.52 & 19.62 & 19.02 & 17.88 \\
8 & 2.56 & 3.8 & 7.98 & 11.4 & 11.78 & 12.54 & 12.2 & 11.02 \\
9 & 3.3 & 4.5 & 6.3 & 8.4 & 8.7 & 8.8 & 8.7 & 8.5 \\
MEAN & 3.42 & 6.25 & 8.57 & 11.73 & 13.64 & 14.37 & 13.92 & 12.93 \\
\hline
\end{tabular}

PAH concentrations in amniotic fluid of nine pregnant women who received infusions at a rate of $380 \mathrm{mcg} / \mathrm{min} / \mathrm{Kg}$ during 30 minutes are shown in Tab. I. PAH increased in all subjects and this increment continued for two or more hours after the interruption of the infusion. For the same 9 women Figure 3 shows that the mean PAH concentration in amniotic fluid increases as a linear function of time $(r=0.66, p<0.001)$. The mean slope was $5.18 \mathrm{mcg}$ per $\mathrm{ml}$ and per hour $( \pm 0.9 \mathrm{SE})$.

When the fetus was dead a completely different pattern was observed (Fig. 4). While in live fetuses (Fig. 4, left) the PAH concentration increased until at least two hours after the infusion ceased, in dead fetuses (Fig. 4, right) the highest concentration was observed in the first sample at the end of the infusion and began to decrease rapidly following a curve parallel to that of maternal plasma one hour after the interruption of the infusion (Fig. 4, compare left and right parts).

\section{Discussion}

From our results it can be concluded that when PAH is administered to the mother: a) it appears rapidly in amniotic fluid; b) increases during the 
infusion and continues to increase for two hours after its interruption although PAH concentration in maternal plasma falls to very low limits. c) $\mathrm{PAH}$ disappears from amniotic fluid very slowly.

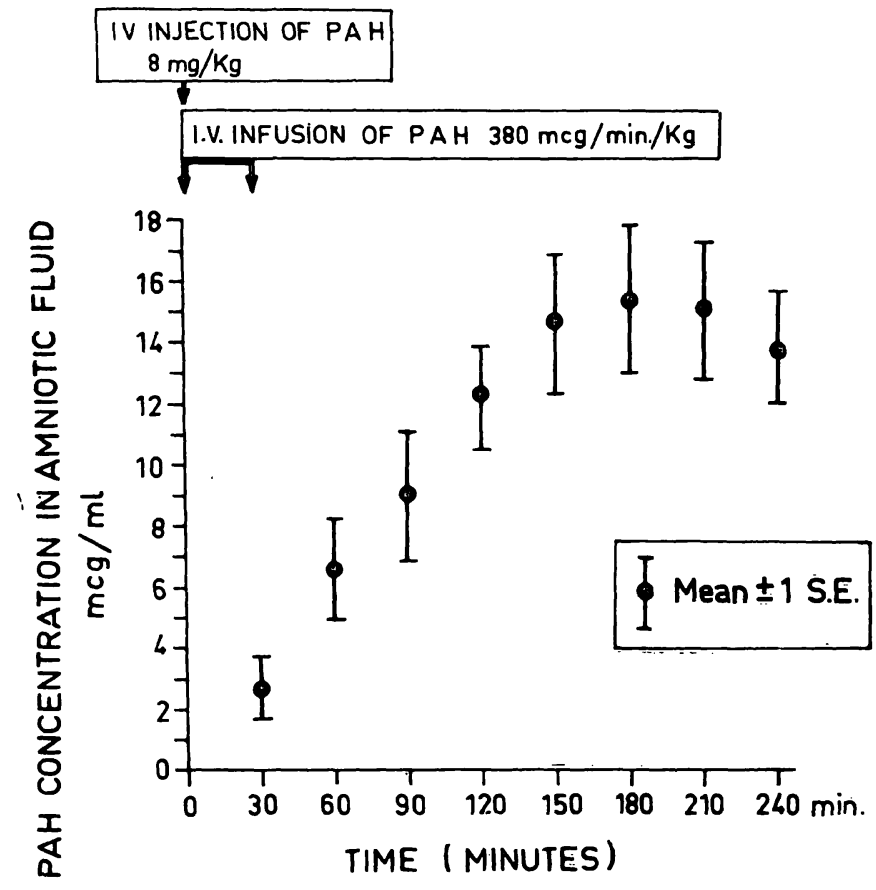

Fig. 3. PAH concentration in amniotic fluid in relation with time. Average and standard error obtained from 9 pregnant women with live fetuses.

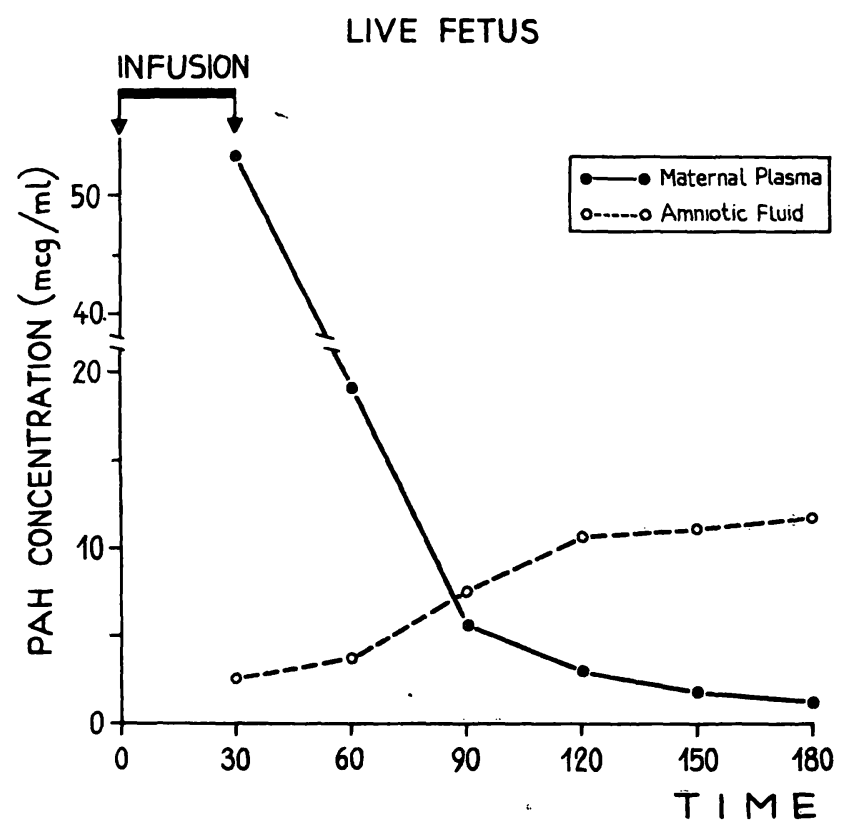

d) Concentration in amniotic fluid may increase above that in maternal plasma if the infusion is prolonged for a sufficient time.

Para-aminohippurate is cleared from blood by the kidney. In human adults 99 per cent of the PAH that enters the organ is eliminated to the urine but only 60 per cent of it is excreted by the normal neonatal kidney (11).

The progressive rise of amniotic PAH concentration may be explained as follows (Fig. 5). PAH diffuses from maternal to fetal blood through the placenta. The fetal kidney removes PAH from fetal blood and concentrates it in urine. Periodic fetal micturition [5] causes the rise of PAH concentration in amniotic fluid. This is in agreement with the idea that the fetal kidney plays a major role in the composition of amniotic fluid during the last trimester of pregnancy.

Also, PAH may return from amniotic fluid to fetal blood mainly because of fetal swallowing, and again excreted into this compartment through the urine after being concentrated by the kidney. It must be postulated that the fetal kidney is much more efficient than the placenta in removing PAH from fetal blood. Consequently, this mechanism maintains a recirculation of this substance between amniotic fluid and the fetus (Fig. 5).

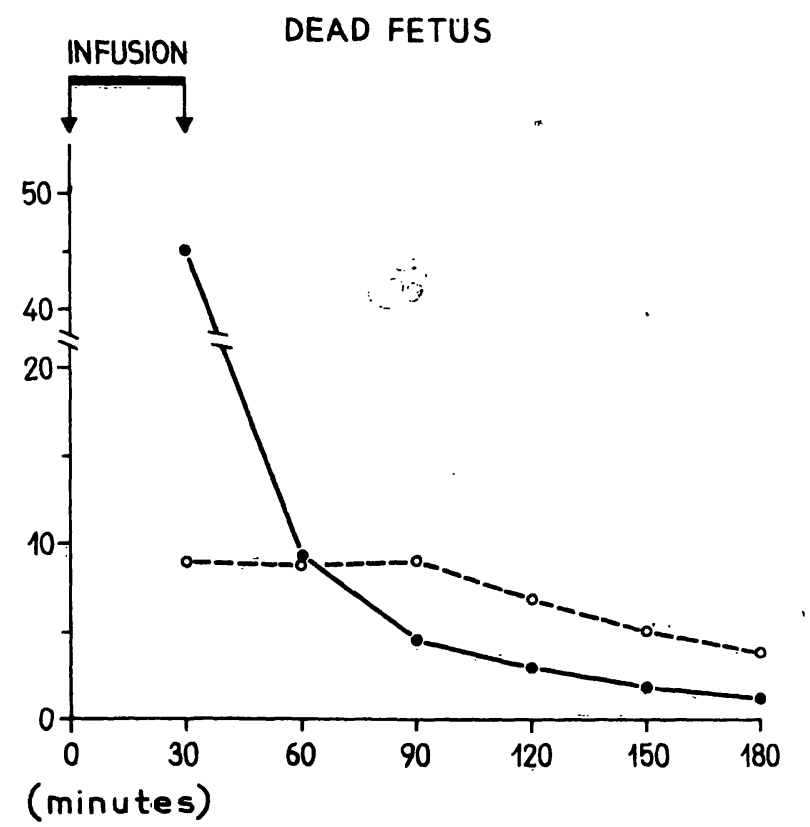

Fig. 4. PAh concentrations in maternal plasma and in amniotic fluid of two patients, one with a dead fetus (right) and the other with a live fetus (left). Both received an $\mathrm{i} / \mathrm{v}$ infusion of $380 \mathrm{mcg} / \mathrm{min} / \mathrm{kg}$. Note the different pattern of PAH concentration in amniotic fluid in both subjects. 


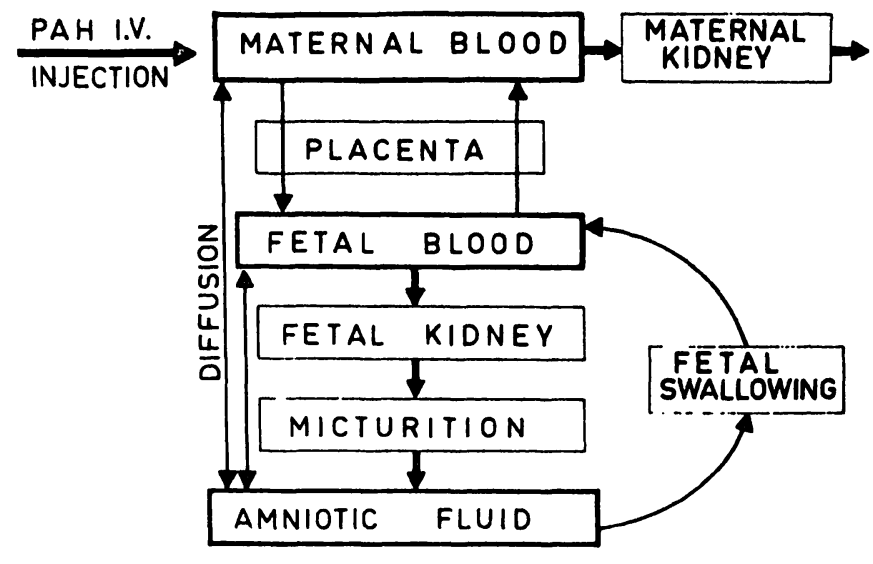

Fig. 5. Working hypothesis to explain the progressive rise of PAH in amniotic fluid and its slow disappearance in cases with live fetuses.

This would explain the lack of correlation between the concentrations in maternal plasma and in amniotic fluid after the infusion was interrupted as well as the slow disappearance of $\mathrm{PAH}$ from amniotic fluid.

Diffusion of PAH between maternal and fetal blood on one side and amniotic fluid on the other, through the walls of the vessels in the ovular membranes and the umbilical cord, may also exist as it is accepted for other substances [3,10]. This mechanism would not play a major role in the concentration of PAH in amniotic fluid, in subjects with live fetuses.

When the fetus is dead, none of the above mechanisms is working except diffusion from maternal blood into amniotic fluid and viceversa which is probably enhanced by an alteration in the ovular membranes due to fetal death.

Our results also show that mean PAH concentration in amniotic fluid increases as a linear function of time until $\mathbf{1 5 0}$ minutes after the onset of the infusion.

Assuming that within these limits, the slope of each individual curve is an estimation of the fetal ability to concentrate PAH in amniotic fluid, a clinical test may be designed selecting two samples with one hour interval (i.e. 60 and 120 minutes). The difference of PAH concentrations between samples corresponds to the hourly increment in that concentration and may be employed as an estimator of fetal health.

\section{Summary}

There are few studies in which substances mainly cleared by the kidney are injected tc the mother and the time course of their concentrations in amniotic fluid is analyzed. This type of studies may contribute to the knowledge of the transference of substances through the mother-fetusamniotic fluid complex.

Thirteen pregnant women were studied. Eleven with normal term pregnancies, and the remaining two mothers were at the 36 th week of gestation and their fetuses were dead.

A saturationdose of para-amino-hippurate (PAH) $(8 \mathrm{mg} / \mathrm{kg})$ was administered intravenously to all subjects. This dose was followed by a continuous infusion at a rate of $380 \mathrm{mcg} / \mathrm{min} / \mathrm{kg}$ during 30 minutes in 11 mothers. In one of the remaining subjects, the infusion rate was $240 \mathrm{mcg} /$ $\mathrm{min} / \mathrm{kg}$ during 160 minutes and in the other, it was $50 \mathrm{mcg} / \mathrm{min} / \mathrm{kg}$ for 450 minutes.

Samples of maternal blood and amniotic fluid were simultaneously obtained, before PAH administration and at variable intervals thereafter.

In mothers with live fetuses, PAH concentration in amniotic fluid increased not only during the infusion but also for at least two hours after its interruption (Fig. 2, Tab. I). When the infusion lasted enough and with stabilized PAH concentration in maternal plasma, amniotic fluid concentration of PAH attained higher values than in the mother (Fig. 1). Disappearance of PAH from amniotic fluid was very slow (45\% in 5 hours) (Fig. 2).

In cases with dead fetuses, the pattern of PAH concentration in amniotic fluid was completely different. The highest concentration was observed already in the first sample at the end of the infusion. From there on, no increment was recorded, and as soon as maternal blood concentration fell below the values of amniotic fluid, PAH began to disappear from this compartment at a much faster rate (45\% in 1 hour) (Fig. 3).

The progressive rise of PAH in amniotic fluid may be explained as follows: (Fig. 5). PAH diffuses from maternal blood to fetal blood through the placenta. The fetal kidney removes PAH from fetal blood and concentrates it in urine. Periodic fetal micturition causes the rise of PAH in amniotic fluid. PAH may return from amniotic fluid to fetal blood mainly because of fetal swallowing; and the larger part of this PAH will be again excreted by the kidney into the amniotic compartment. This mechanism would explain the slow disappearance of the substance from amniotic fluid after the end of the infusion, and also the lack of correlation between concentrations in maternal plasma and amniotic fluid. Diffusion of PAH between blood and amniotic fluid may also exist through the walls of the vessels of the ovular membranes and the 
vessels of the umbilical cord; this mechanism would play a minor role in the concentration of PAH in amniotic fluid in subjects with live fetuses.

Our results also show that mean PAH concentration in amniotic fluid increases as a linear function of time until 150 minutes after the onset of PAH administration to the mother (Fig. 4). Assuming that the slope of each individual is an estimation of the fetal ability to concentrate PAH in amniotic fluid, a clinical test may be designed selecting two samples with one hour interval (i.e. 60 and 120 minutes). The difference of PAH concentration between samples may be employed as an estimator of fetal health.

Keywords: Amniotic fluid, fetal health, feto-maternal transfer, fetus, pregnancy

\section{Zusammenfassung}

Der Transfer von Para-Amino-Hippursäuren von der Mutter in das Fruchtwasser

Es gibt wenige Untersuchungen, bei denen nierenpflichtige Substanzen der Mutter injiziert werden mit dem Ziel, das zeitliche Erscheinen im Fruchtwasser zu analysieren. Diese Art von Studien könnte zu unserem Wissen über den Transfer von Substanzen durch den Mutter-Fetus-Fruchtwasser-Komplex beitragen.

13 schwangere Frauen wurden untersucht: $11 \mathrm{mit}$ Schwangerschaften am Termin; 2 Mütter waren in der 36. Schwangerschaftswoche; ihre Feten waren abgestorben.

Eine Sättigungsdosis von Para-Amino-Hippursäure (PAH) $(8 \mathrm{mg} / \mathrm{kg}$ ) wurde allen Patientinnen intravenös verabfolgt. Dieser Medikation folgte eine Dauerinfusion mit einer Rate von $380 \mathrm{mcg} / \mathrm{min} / \mathrm{kg}$ während 30 Minuten bei 11 Patientinnen. Bei einer der verbleibenden Frauen betrug die Infusionsrate $240 \mathrm{mcg} / \mathrm{min} / \mathrm{kg}$ während 160 Minuten und bei der anderen belief sich die Rate auf $50 \mathrm{mcg} / \mathrm{min} / \mathrm{kg}$ über 450 Minuten.

Simultan wurden Proben aus dem mütterlichen Blut und der Amnionflüssigkeit gewonnen, und zwar jeweils vor PAH-Gabe und nach variablen Zeitintervallen danach.

Bei den Müttern mit lebenden Feten stieg die PAH-Konzentration imFruchtwasser nicht nur während der Infusion, sondern auch mindestens 2 Stunden nach Absetzen derselben an (Fig. 2) (Tab. I). Wenn die Infusion lange genug andauerte und stabilisierte PAH-Konzentrationen im mütterlichen Plasma vorlagen, erreichte die PAH-Konzentration im Fruchtwasser höhere Werte als in der Mutter (Fig. 1). Die Elimination der PAH aus dem Fruchtwasser erfolgte sehr langsam (45\% in 5 Stunden) (Fig. 2).

In den Fällen mit abgestorbener Frucht war das Verhaltensmuster der PAH-Konzentration im Fruchtwasser ganz anders: Die höchste Konzentration war schon in der ersten Probe am Ende der Infusion erreicht. Von diesem Zeitpunkt an wurde kein weiterer Zuwachs beobachtet; so- bald die mütterliche Blutkonzentration unter jene im Fruchtwasser absank, verschwand die PAH aus diesem Kompartiment mit einer viel höheren Rate $(45 \%$ in 1 Stunde) (Fig. 3).

Der zunehmende Anstieg von PAH im Fruchtwasser kann wie fólgt erklärt werden (Fig. 5): PAH diffundiert via Plazenta vom mütterlichen in das fetale Blut. Die fetale Niere entfernt das PAH aus dem fetalen Blut und konzentriert die Substanz im Urin. Periodische fetale Miktionen verursachen den PAH-Anstieg im Fruchtwasser. PAH kann vorwiegend durch das Verschlucken von Fruchtwasser durch den Feten in das fetale Blut zurückkehren. Der größte Teil dieses PAH wird wieder durch die Nieren in das Fruchtwasserkompartiment ausgeschieden. Dieser Mechanismus würde das langsame Verschwinden der Substanz aus dem Fruchtwasser nach Beendigung der Infusion erklären und auch eine Erklärung für den Mangel an Korrelation zwischen der Konzentration im mütterlichen Plasma und im Fruchtwasser liefern. Eine Diffusion von PAH zwischen Blut und Fruchtwasser kann ebenfalls durch die Gefäße der Eihautmembranen und die Nabelschnurgefäße erfolgen. Dieser Mechanismus würde eine geringere Rolle bei der Konzentration von PAH im Fruchtwasser bei lebenden Feten spielen.

Unsere Resultate zeigen auch, daß die mittlere PAH-Konzentration im Fruchtwasser bis zur 150. Minute nach Beginn der PAH-Verabfolgung an die Mutter in einer linearen Funktion über die Zeit zunimmt. (Fig. 4). Unter der Annahme, daß die Steigung der Geraden bei jedem Individuum ein Schützwert für die fetale Fähigkeit, PAH im Fruchtwasser zu konzentrieren, darstellt, könnte ein klinischer Test ausgearbeitet werden, der zwei Stichproben mit 1 Stunde Intervall voneinander trennt (d.h. 60 und 120 Minuten). Die Differenz in der.PAH-Konzentration zwischen den Stichproben könnte als Parameter für das fetale Wohlergehen verwendet werden.

Schlüsselwörter: fetales Wohlergehen, fetomaternaler Transfer, Fetus, Fruchtwasser, Schwangerschaft

\section{Résumé}

Transference de para-amino-acide hippurique de la mère au liquide amniotique

Il existe jusqu'à présent peu d'études portant sur l'injection à des femmes enceintes de substances principalement éliminées par les reins et sur l'analyse de leur temps de concentration dans le liquide amniotique. Or, de tels examens pourraient aider à élargir notre savoir sur le transfert de substances à travers le complexe mère-foetusliquide amniotique.
Notre présent article porte sur l'examen de 13 femmes enceintes. Onze grossesses ont eu une issue normale à terme tandis que les deux dernières se sont achevées à la 36ème semaine avec des foetus morts.

Une dose de saturation de para-amino-acide hippurique (PAH) $(8 \mathrm{mg} / \mathrm{kg})$ avait été administrée à tous les sujets par injection intraveineuse. Cette dose a été suivie d'une infusion continue à un taux de $380 \mathrm{mcg} / \mathrm{min} / \mathrm{kg}$ pendant 30 minutes à 11 mères, à la 12 ème à un taux de $240 \mathrm{mcg} /$ 
$\mathrm{min} / \mathrm{kg}$ pendant 160 minutes et à la dernière à un taux de $50 \mathrm{mcg} / \mathrm{min} / \mathrm{kg}$ pendant 450 minutes.

Des échantillons de sang maternel et de liquide amniotique ont été prélevés simultanément avant administration de $\mathrm{PAH}$ et à divers intervalles après cette administration.

Chez le mères aux foetus vivants la concentration de PAH dans le liquide amniotique a augmenté non seulement durant l'infusion, mais aussi pendant deux heures au moins après son interruption (Fig. 2) (Tab. I). Lorsque l'infusion avait duré suffisamment et que la concentration de PAH s'était stabilisée dans le plasma maternel, on observa que la concentration de PAH dans le liquide amniotique atteignait des valeurs plus élevées que chez la mère (Fig. 1). La disparition de PAH du liquide amniotique a augmenté non seulement durant l'infusion, mais aussi pendant deux heures au moins après son interruption (Fig. 2) (Tab. I). Lorsque l'infusion avait duré suffisamment et que la concentration de PAH s'était stabilisée dans le plasma maternel, on observa que la concentration de PAH dans le liquide amniotique atteignait des valeurs plus élevées que chez la mère (Fig. 1). La disparition de PAH du liquide amniotique ne se fit que très lentement (45\% en 5 heures) (Fig. 2).

Dans les cas des foetus morts, la structure de la concentration de PAH dans le liquide amniotique fut totalement différente. La concentration la plus élevée était observée dès le premier échantillon à la fin de l'infusion. A partir de là, on n'enregistra aucun incrément et dès que la concentration dans le sang maternel tomba au-dessous des valeurs du liquide amniotique, le PAH commença à en disparaître à un taux beaucoup plus rapide ( $45 \%$ en 1 heure) (Fig. 3).

La hausse progressive du PAH dans le liquide amniotique peut être expliquée comme suit: (fig. 5). Le PAH se diffuse du sang maternel dans le sang foetal à travers le placenta. Le rein foetal retire le PAH du sang foetal pour le concentrer dans l'urine. La miction foetale périodique provoque la hausse de PAH dans le liquide amniotique. Le PAH peut retourner du liquide amniotique au sang foetal principalement du fait que le foetus avale, et la plus grande part de ce PAH sera à nouveau éliminée par le rein dans le «secteur» amniotique. Ce mécanisme expliquerait la lente disparition de la substance de liquide amniotique après la fin de l'infusion ainsi que le manque de corrélation entre les concentrations dans le plasma maternel et le liquide amniotique. La diffusion de PAH entre le sang et le liquide amniotique peut aussi exister à travers les parois des vaisseaux des membranes ovulaires et des vaisseaux du cordon ombilical; ce mécanisme jouerait un rôle moindre dans la concentration de PAH dans le liquide amniotique chez les sujets avec foetus vivants.

Nos résultats montrent aussi qu'une concentration moyenne de PAH dans le liquide amniotique augmente comme une fonction linéaire de temps jusqu'à 150 minutes après le début de l'administration de PAH à la mère (Fig. 4). Présumant que la «courbe» de chaque individu est une estimation de la capacité foetale à concentrer le PAH dans le liquide amniotique, un test clinique peut être assigné pour sélectionner deux échantillons peut être utilisée comme facteur d'estimation de la santé du foetus.

Mots-clés: Foetus, grossesse, liquide amniotique, santé foetale, transfert foeto-maternel.

Acknowledgement: We are greatly indebted to Mrs. Alba M. Izquierdo and Miss Nora Brandon for their assistance in the care of the patients during the study.

\section{Bibliography}

[1] ALEXANDER, D.P.,D.A.NIXON: The foetal kidney. Brit. Med. Bull. 17 (1961) 112

[2] BASSO, A., A. FERnÁNDEZ, O. AlthabE, G. SABINI, H. PÍRIZ, R. BELITzKY: Passage of mannitol from mother to amniotic fluid and foetus. Accepted for publication in Obstet. and Gynec., 1976

[3] BLAKE, D. A., L. S. BURNETT, B. C. MIYASAKI, J. A. LONGST RETH, T. M. KING: Pharmacokinetics of intra-amniotically administered hyperosmolar urea. Amer. J. Obstet. Gynec. 124 (1976) 245

[4] BRANDES, J. M., H. ABRAMOVICH, A. PERETZ: Passage of inulin from gravida to fetus in normal pregnancy and during cesarean section. Obstet. and Gynec. 37 (1971) 877

[5] CAMPBELL, S., N. WLAdimirofF, C. J. DEWHURST: The antenatal measurement of fetal urine production. J. Obstet. Gynaec. Brit. Cwlth. 80 (1973) 680
[6] HAMBURGER, J.: Nouveaux procédés d'exploration fonctionnelle du rein. Flammarion, Paris 1949

[7] HANON, F., M.COQUOIN-CARNOT, P. PIGNARD: Etude de la fonction excrétoire du rein anténatal par ingestion d'acide para-amino-hippurique per partum. Gynéc. Obstét. 56 (1957) 64

[8] LIND, T., W. Z. BILlEWICZ, G. A. CHEYNE: Composition of amniotic fluid and maternal blood through pregnancy. J. Obstet. Gynaec. Brit. Cwlth. 78 (1971) 505

[9] ROSA, P.: Etude des échanges d'inuline entre mère et foetus. Acta Clin. Belg. 4 (1949) 169

[10] SEEDS, A.E., J. J. SCHRUE FER, J. A. REINHARDT, K. D. GARLID: Diffusion mechanism across human placental tissue. Gynec. Invest. 4 (1973) 31

[11] STAVE, U.: Physiology of the perinatal period. Appleton Century-Crofts, New York 1970

Received June 22, 1976. Accepted July 2, 1976.
Dr. Omar Althabe

Casilla de correo 627

Montevideo, Uruguay 